\title{
Children's experiences of democracy, participation, and trust in school
}

\author{
Robert Thornberg and Helene Elvstrand
}

\section{Linköping University Post Print}

\section{Tweet}

N.B.: When citing this work, cite the original article.

Original Publication:

Robert Thornberg and Helene Elvstrand, Children's experiences of democracy, participation, and trust in school, 2012, International Journal of Educational Research, (53), 44-54.

http://dx.doi.org/10.1016/j.ijer.2011.12.010

Copyright: Elsevier

http://www.elsevier.com/

Postprint available at: Linköping University Electronic Press

http://urn.kb.se/resolve?urn=urn:nbn:se:liu:diva-75313 


\title{
Children's experiences of democracy, participation, and trust in school
}

\author{
Robert Thornberg* and Helene Elvstrand** \\ *Department of Behavioural Sciences and Learning, Linköping University, Linköping, Sweden \\ **Department of Social and Welfare Studies, Linköping University, Linköping, Sweden
}

\begin{abstract}
The aim of this paper is to investigate children's views and experiences of democracy and pupil participation in relation to everyday school life, and to let their voices be heard on these issues. The data for this paper was derived from two ethnographic research projects conducted in three elementary schools in Sweden. In the classes investigated at two of the three schools, the adults are those who make decisions about school and classroom rules. Pupils are seldom given any opportunity to create, modify or repeal formal rules through open negotiations. In contrast, at the third school, children's influence and their ability to have a say are an important explicit goal for the teachers. Nevertheless, as well as in the two other schools, even in this school with the declared goal of working with democracy in this way, we found obstacles and limitations that counteracted school democracy: (a) discontinuity, (b) the long-term interaction pattern of teacher power and pupil subordination in the school organisation, which in turned encouraged and educated compliance with authority rather than deliberative democratic participation, (c) naive trust in teachers, (d) the school process of suppressing children's voices, and (e) unfair inconsistencies constructed by teachers
\end{abstract}

Keywords: democracy, participation, children's voice, hidden curriculum, trust

\section{Introduction}

According to their official curriculum document, schools in Sweden should conduct citizenship education in democracy as well as being a democratic arena where the pupils can practise democracy in their day-to-day school life (Utbildningsdepartementet, 1998). This is based on the Swedish Education Act, which states that it is duty of everyone working in schools to promote democratic practices at work (Skollagen, 1985:1100, Chapter 1, 2§). In addition, documents from the National Agency for Education have advocated the application of "deliberative conversations" based on the so- called deliberative democracy model as an essential aspect of values education (e.g., Englund, 2000; Skolverket, 2006). The main idea is that pupils as well as others in school develop a viewpoint on matters by listening, deliberating, finding arguments, and evaluating in a collective effort to use these conversations so as to find values and norms on which everyone can agree (cf., Englund, 2006). The Swedish political intentions regarding school democracy and pupil participation reflect the international movement for children's rights and the United Nations of the Convention on the Rights of the Child (1989), in which Articles 12-13 assert the child's right to freely express his or her opinion on all matters affecting him or her, and the right to seek, receive and impart information and ideas of all kinds. The aim of this paper is to investigate children's views and experiences of democracy and pupil participation in relation to everyday school life, and to let their voices be heard on these issues. Instruction and management are two main teacher practices in the classroom (cf., Arends, 1997), and we were mostly concerned about pupil participation in both. The main points of focus were relationships and interaction patterns between teachers and pupils in everyday school life when we investigated and analysed the issues of school democracy and pupil participation.

\section{Theoretical framework}

School democracy and democratic education are essential components in the progressive movement of schooling which has its roots in early Pragmatism (e.g., Dewey, 1916). Accord- 
ing to this theoretical perspective, democracy in school is not confined to formal procedures, such as class councils or other kinds of school democratic meetings, but it is a way living and a form of relationship within the school community. Moreover, an essential idea is that democracy is best learned by practicing it in everyday life, in relationships in school and in classrooms (Dewey, 1916; Gutmann, 1987).

According to the new sociology of childhood, children are both constrained by structure and at the same time active agents acting in and upon structure. They do not simply internalise the social world but strive to make sense of their culture and to participate in it (Corsaro, 2005; Prout \& James, 1997). "Children create and participate in their own unique peer cultures by creatively taking or appropriating information from the adult world to address their own peer concern" (Corsaro, 2005, pp. 18-19). According to the domain theory (Nucci, 2001; Smetana, 2006; Turiel, 1983, 2006), cognitive structures are developed and organised within the boundaries of fundamental categories, or so-called domains, as a result of being constructed through the children's interactions with the social environment. Based on that, the theory claims that children construct their social knowledge in three different domains: (1) the moral domain, (2) the conventional domain, and (3) the personal domain. Here, morality refers to conceptions of human welfare, justice, and rights. In contrast, social conventions refer to more arbitrary norms, such as etiquette or manners, which coordinate individuals' interactions in social systems. Social conventions are based upon authority, traditions or customs rather than moral reasons such as social justice or preventing harmful effects. Personal issues refer to 'the set of actions that the individual considers to pertain primarily to oneself and, therefore, to be outside the area of justifiable social regulation' (Nucci, 2001, p. 54; also see Helwig, 2006). Thus, these actions are not matters of right and wrong but of personal preferences and choice. Examples of such actions within Western culture are actions that focus on the state of one's own body, privacy and choice of friends, partners, or recreational activities. A huge body of research has shown that moral, convention and personal issues emerge as distinct conceptual frameworks (i.e. domains) at very early ages among children in Western as well as non-Western cultures (for reviews, see Nucci, 2001; Turiel, 2006). As a result, quite early on children have a tendency of critically reflecting upon and judging some social conventions (in forms of social norms or rules) they meet in their environment (e.g., family or school) as morally wrong (e.g., unfair) or in conflict with what they think should be up to them to decide upon (i.e., personal domain).

Hence, according to the domain theory, children (as well as adults) interpret their experiences and reflect upon them; some social norms or rules will be accepted while others will be questioned or doubted, or even rejected by them (Neff \& Helwig, 2002; Wainryb, 2006). "The active stance of individuals in relation to their social environment results in both shared and non-shared aspects of culture, both within and between individual members of society" (Neff \& Helwig, 2002, p. 1431). Children can have different views on the meaning of social practices and of values and norms regulating these practices. They can even develop critical attitudes to different aspects of social milieus they live in, and oppose or even try to change them (Wainryb, 2006). Both the new sociology of childhood and the domain theory help us to better understood active agency and critical stance as well as compliance among children by pointing to different aspects of their social processes and representations (active participation in peer cultures and different domains of social knowledge).

At the same time, children are often expected to show more or less unquestioning obedience and loyalty to their parents and teachers. They are dependent on adults and subordinated to adult control (Alderson, 1999). According to an ethnographic research conducted by Devine $(2000,2002)$ in primary schools in Ireland, pupils usually have neither any say nor are they consulted regarding rules or other aspects of their school lives. The wide-spread perception among pupils that decisions on rules are made by teachers and head teachers and that 
pupils have no say, has also been found in British studies (Davies, 2000; Thomas \& O’Kane, 1999), a Canadian study (Raby, 2005, 2008; Raby \& Domitrek, 2007), and Scandinavian investigations (Aspán, 2009; Fjeldstad \& Mikkelsen, 2003; Johansson \& Johansson, 2003). Empirical research on democracy and pupil participation in school is still rare in Sweden, but available findings indicate that Swedish pupils' opportunities to have a say and participate as democratic agents in school are strongly restricted (Aspán, 2009; Dovemark, 2004; Ekholm \& Lindvall, 1991; Forsberg, 2000; Selberg, 1999). For example, Aspa n (2009) found in her ethnographic study that teachers were preoccupied with directing and morally and socially rearing the pupils rather than creating pedagogical conditions that promote pupils' critical and reflective thinking, and that also support communication that involves the pupils' own perspectives and interests.

Thus, there is an embedded conflict between authoritarian/traditional and democratic/progressive ideals in the school structure and its disciplinary practices (Millei \& Raby, 2010). We share Millei and Raby's (2010) understanding of classroom discipline as "a technology of the school to deliver social training and to regulate the student population"' (p. 28), and thus it is imbued with power. As Bernstein (2000) puts it, this regulative discourse is a moral discourse, because it creates the criteria that give rise to character, conduct, manners etc. Rules, regulations, disciplinary processes, and conflicts of values in everyday school life can be understood and investigated in terms of a hidden curriculum (cf., Jackson, 1968). Meighan and Siraj-Blatchford (1997) define the hidden curriculum as "all the things that are learnt during schooling in addition to the official curriculum" (p. 65). It is a "set of implicit messages relating to knowledge, values, norms of behaviour and attitudes that learners experience in and through educational processes"' (Skelton, 1997, p. 188), and has always a normative or moral component (Portelli, 1993). The function of the hidden curriculum is social control, and has been variously identified as political socialisation, inculcation of values, maintenance of class structure, training in obedience and docility, maintenance of dominant normative discourses etc. (Vallance, 1983).

\section{Method}

The data for this paper was derived from two ethnographic research projects conducted in elementary schools in Sweden. The schools are located in two medium sized towns. In the first research project, fieldwork was conducted in two schools, for three to five days each school week from October 2002 to May 2003 in the first school, and then from November 2003 to May 2004 in the second school. Two pre-school classes, two classes in Grade 2, and two classes in Grade 5 (i.e., six classes) participated. 141 pupils and 13 teachers participated in this first research project. Since different categories of teachers collaborated in teams up to Grade 3 in the two schools, these are also represented in the project. Three of the 13 were preschool teachers, five were elementary teachers, three were free-time pedagogues (a particular teacher category in Sweden, working both in classroom settings and in after-school centres), one was a music teacher, and one was a physical education teacher (the two latter teachers taught pupils from all grades). The amount of teaching experience varied widely among the teachers but most of them had worked as teachers for many years. The issues concerning values and norms in everyday school life were observed and documented by field notes and audio-recordings. Informal conversations with teachers and pupils were also held. Moreover, qualitative interviews with the teachers were conducted in order to examine how teachers reasoned about the practice and the content of everyday values education, discipline and school rules. In addition, qualitative group interviews with 139 pupils (in total, 49 groups with 2-4 pupils in each group) were conducted in order to examine how pupils reason and make sense of school rules and teachers' discipline and values education practice. 
In the second research project, fieldwork was conducted from September 2002 to June 2003 (approximately two days a week) in two classes in Grade 4 at a third school and then interviews and some field visits were conducted from January 2004 to June 2004 in the same two classes but in Grade 5. Forty-two pupils, nine ordinary teachers, and four substitute teachers participated in this second project. Six of the nine ordinary teachers were elementary teachers, one was a special educator, and two were free-time pedagogues. Three of the four substitute teachers had begun but not completed their teacher training. The fourth substitute teacher lacked teacher training. Since different categories of teachers collaborated in teams in this school and since one of the two classes had many class teachers who succeeded each other during the fieldwork period, these teachers are also represented in the project. The focus in the second research project was specifically confined to democracy and pupil participation in everyday school life. Observations and informal conversations were conducted and documented by field notes. Individual qualitative interviews with 20 pupils were conducted. In these interviews the researcher gave children paper, crayons and pencils, and asked them to draw a picture on the theme, "A day in my school". When they had finished their drawings, the researcher invited the children to talk about their drawings. Furthermore the children were also invited to write reflections books about things they could decide on themselves as regards their school life. In total, the data for this paper was based on fieldwork from three elementary schools (eight school classes) in which 183 pupils and 26 teachers participated.

In line with the new sociology of childhood, we used what Mandell (1991) terms a leastadult-role in our fieldwork and conversations with children. We avoided any position of authority (by not behaving like a teacher or someone in charge), and we were closer to the children rather than the teachers (cf., Corsaro \& Molinari, 2000; Mayall, 2000; Thorne, 1993). During our conversations, we approached the children and treated them as competent informants and commentators on their own lives as pupils in school (cf., Prout, 2002), and we asked them to help us as adults to understand their life in school as pupils (cf., Mayall, 2000). The qualitative analysis of the fieldwork data was performed using procedures influenced by the grounded theory methodology (e.g., Charmaz, 2006; Glaser \& Strauss, 1967). The analysis and findings about school rules and management were derived from the first research project. The analysis and findings about instruction and schoolwork were derived from the second research project. Similarities and differences were analysed by comparing the data and the findings from the two research projects.

\section{Pupil participation and subordination}

In the classes investigated at two of the three schools, the adults are those who make decisions about school and classroom rules. Pupils are seldom given any opportunity to create, modify or repeal formal rules through open negotiations. The teacher style in these classes is rather traditional. Pupils are expected to behave nicely, do what teachers tell them to do, and to comply with all kinds of school and classroom rules. In contrast, at the third school, children's influence and their ability to have a say are an important explicit goal for the teachers. They actively work to create lessons and learning situations with the aim of encouraging children's activity and making participation possible. The pupils' participation in the day-to-day work in school is often expressed in terms of negotiations for influence, which means that participation can be understood more in terms of relations and interaction than in terms of the outcome, i.e., the process rather than the result. This kind of informal democracy (cf., Dewey, 1916) is the way the teachers most often try to implement school democracy in the third school. The following excerpt is taken from the third school.

It is an English lesson. The teacher, Petra, is talking about the homework for the next week where the task is to bring an object from home and ask questions about the object, e.g., "Is it 
new or is it old?', Carl raises his hand and asks if he can bring his rabbit to school. Petra says it's difficult because there are some pupils who are allergic to furry animals. Benham then asks if they can bring a stick insect. More pupils join in the discussion and try to put more limits on what kind of animals they can bring. Petra says they must discuss what object they can bring with their parents. But if they decide to bring a rabbit and keep it in the cupboard for the whole day, they have to consider the conditions for the rabbit. Petra ends the conversation by saying, "Think over your decision carefully before you bring a living creature and keep it in the cupboard”' (from Field notes, Grade 4).

The excerpt above is an example of how children in this classroom try to have a say by negotiating. The traditional teacher would probably say, "No, we do not bring animals to school" and that would be the end of the discussion. In this classroom the teacher Petra thought it was important that children got a reason for the different rules. She also thought that discussion has an intrinsic value. It helps children to develop democratic skills; in this case to discuss and learn to evaluate different arguments. The children in this school were used to being allowed to be active and take part in different discussions and decisions. Children themselves could remember situations when they had a say. Nils wrote in his reflections book about such an experience.

How you mark a book!!! It was Wednesday afternoon. We were marking books. Then I yelled: You are writing in ink in my book, it will be ruined! Many other kids don't want to have ink in their books. And then it was agreed by everyone that we shouldn't have ink in our books (a boy in Grade 4, reflections book).

From Nils' perspective this was an important experience. He had been able to make a suggestion and the pupils and the teacher had listened to him. His suggestion had also made a difference.

Moreover, our ethnographic data indicate that children's views on their participation are closely connected with their feeling of participation. "It feels like I can decide anyway. It feels that I'm the one who can decide"' (a girl in Grade 1). As we mentioned before, participation is not only about the outcome, it is more about relations, trust and interaction. In the third school mentioned above, there was a very clear aim to enhance and promote children's ability to have a say and to work actively with pupils' participation, and the children themselves express that they can have a say in some way. But even in this school with the declared goal of working with democracy in this way, we found obstacles and limitations. The two school classes in this school had very different experiences during the year the fieldwork was conducted. One of the two classes experienced a year of continuity, which means they had two main teachers during the year. The other class experienced a year of discontinuity when they had five different teachers during the year, in addition to other involved teachers (i.e., substitute teachers and two different free-time pedagogues as well as a special educator who had a few lessons per week for some of the pupils in the class). These different experiences give the children different feelings about their school life. Discontinuity creates an obstacle to building up solid trust and democratic relations between pupils and teachers. For example, one pupil expresses the discontinuity in the following way, "Everything is changing all the time and it's bad because you don't know what's happening next'.

The discontinuity means for instance that things the pupils have decided in a democratic way with one teacher could be withdrawn by another teacher without any explanation about the change. There is also a discontinuity among the different teachers in terms of their views and actions related to pupil participation and school democracy. Among the teachers the opinion differs to what extent the pupils should be able to have a say in the classroom. For some of the teachers, pupils' influence and participation in the classroom is a desirable goal while others do not think it is a necessary condition. Thus, in spite of the strong ambitions for 
school democracy from some of the teachers in the third school, the pupils' opportunities to have a say are still limited.

The long-term interaction pattern of teacher power and pupil subordination in the school organisation appears to be a resilient structure. Compliance with authority rather than deliberative democratic participation is still an inherent part of the hidden curriculum. Sherman (1996) calls the process of socialisation into rules, routines and subordination in school, "studentizing' in which compliance with authority, rules, time-keeping, routines, and so on ensures their inclusion as a student in the school world as a preparation for the world of work. The norm of obedience to authority is, according to Milgram (1974), a basic element in the structure of social life. Both at home and at school children are expected and told to obey the adults who have authority over them. Milgram argues that this internalised norm in people is problematic because it could result in blind obedience and override people's other internalised norms and values, and even make people harm others, under the influence of an authority in a hierarchical situation, which his classic but controversial series of experiments demonstrated. Morality does not disappear, Milgram argues, but instead shifts to a radically different focus: the person feels a sense of responsibility to the authority but feels no responsibility for the content of the actions that the authority prescribes. In the schools, we found that pupils' subordinated position vis-a '-vis teachers counteracted a lived democracy in school, and hence the political intention of pupil participation and democratic education as well (cf., Dewey, 1916; Englund, 2000, 2006; Gutmann, 1987).

\section{Naïve vs. grounded trust}

Furthermore, the analysis highlights different types of trust pupils have in teachers. One type of trust, especially among the younger pupils, could be labelled naïve trust, i.e., they trust and believe in teachers, just because they are adults and teachers. "They know what's the best for us"' (a girl in Grade 2). This trust can be related to and explained in terms of the adult-child power asymmetry in our society. Naïve trust could be interpreted as a result of the socialisation processes in society in which parents, teachers and other adults influence children to adopt such subordinating beliefs and approaches (e.g., Alderson, 1999; James, Jenks, \& Prout, 2001). Nevertheless, naïve trust, from a moral point of view, can be problematised in a way that Milgram (1974) does (see above) as well as in terms of the fallacy of authority, i.e., claiming that something is true, good, or right simply because someone in authority says so, rather than because it is supported by good arguments or evidence (cf., Fox \& DeMarco, 2001). It can also be problematised in terms of power, devaluation of children's agency and competences, loss of pupil participation, and hidden curriculum.

In contrast, another type of trust in teachers, grounded trust, is also expressed by the pupils. Here pupils trust and believe in teachers because of (a) good arguments and explanations from teachers, and/or (b) fair negotiations and joint participation in decision-makings. Theoretically, whereas grounded trust can be understood as a relationship outcome produced by lived democracy (cf., Dewey, 1916) or informal democracy expressed by deliberative conversations (cf., Englund, 2000), naïve trust as well as distrust can be understood as a relationship outcome produced by a lack of such democratic practices. Hence, the issue of trust is critical in relation to pupil participation and democratic education. The existence of grounded trust as well as distrust and critical engagement among the pupils regarding teachers, influence and rules in the present study indicate that children are not passive receivers but actually active and meaning-making agents in line with the new sociology of childhood (e.g., Corsaro, 2005; Prout \& James, 1997) as well as with the domain theory (e.g., Neff \& Helwig, 2002; Wainryb, 2006). A development from naïve trust to grounded trust can also be interpreted as a part of the development of expertise in democratic competence. 


\section{The school process of suppressing children's voices}

According to observations and interviews, children's voices in terms of having a say, and in terms of democratic participation in decision-making, are suppressed in classroom management and the making of school and classroom rules, as well as in classroom instruction and school work. When the pupils start going to school, there is already a set of explicit school and classroom rules, which they are expected to comply with. Most often it is the adults in school who make decisions about school rules. Pupils are seldom given any opportunity to create, modify or repeal formal rules through open negotiations. Even when school rules are brought up in "school democracy" meetings, they are typically processed in a disciplinary rather than a democratic way. For example, in one of the classes in the study, a class council was conducted every Friday in the classroom. The class teacher wrote down an agenda on the blackboard and then acted as the chair throughout the whole class meeting. According to the class teacher, one of the aims with the class council was to educate the pupils in how democratic meetings function and how to participate in a democratic way.

Nevertheless, the teacher led these meetings in a rather traditional teacher style, asking the pupils questions and evaluating their responses. Observation data show that pupils have to sit nicely and quietly, do as teacher says, and learn to give the "right answers" (see also Thornberg, 2010). Recurrent incidents in school in which pupils have been in fights or broken rules are often issues that teachers brought up in these school democratic meetings. For example, in one of the classes in Grade 2, there were two recurrent items in every class council, "'What has been good this week?" and "What has been bad this week?'” By asking the class these two questions every week in these meetings, the disciplinary function of the class council becomes very clear. For instance, in one of these class meetings, under the item of "What has been good this week?"' a schoolgirl said, "I think it's good that Emil has been better and has not teased me'. The teacher replied with a pleased expression and said to Emil, "Wasn't that nice to hear?', Later, in the class council meeting, the following conversation took place under the item, "What has been bad this week?"

“'I think it was bad during the music class when Daniel teased me”, Fatima says.

“But you hit me!'” Daniel exclaims and looks a little bit angry.

“It's Fatima's turn to talk now”, the teacher says. "If you want to say something, Daniel, then you have to raise your hand and wait for your turn. We don't interrupt someone who is talking." The teacher turns to Fatima again. "What were you saying?"

"Daniel teased me", Fatima replies.

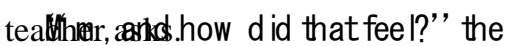

“'First I usually say 'stop it!' And then, after I’ve said 'Stop it!' loads of times, I get tired of doing that and get very angry and start to fight', Fatima says.

“Mm, you got angry when Daniel teased you and he didn’t stop even then you told him to stop lots of times", the teacher says. "But are you allowed to fight?",

“No", Fatima says.

"No, because one of the rules at school is that we are friendly to each other. We're not allowed to fight."' The teacher walks up to the wall where a set of school rules has been put up. "'We're nice to each other. We use civilised language. That's one of the rules at school. If you are to be nice to each other, then you can't fight."

“'No teasing neither', Linus says.

“No, that's right too”, the teacher says. "Teasing and fighting, we don't do things like that in this school. We're nice to each other instead. You have the right to be angry, but you're not allowed to fight or begin to run after someone in the classroom."' The teacher becomes silent and looks seriously at the pupils. "What happens if I get teased? What should I do then?"

Some of the pupils raised their hands. (Field note, Grade 2, class council in the classroom.)

The above excerpt is a typical example under this item of how pupils report how other classmates have broken one or more school rules (often relational rules, i.e., rules about how 
to behave with each other, but a lot of other school rules can also be focused on). The interviews with the children confirm the observational findings of pupil powerlessness in and subordination to the rules and regulations constructed by the adults in school. With very few exceptions, the children report that it is the teachers or the adults in school who create and make decisions about school rules. The children have no say.

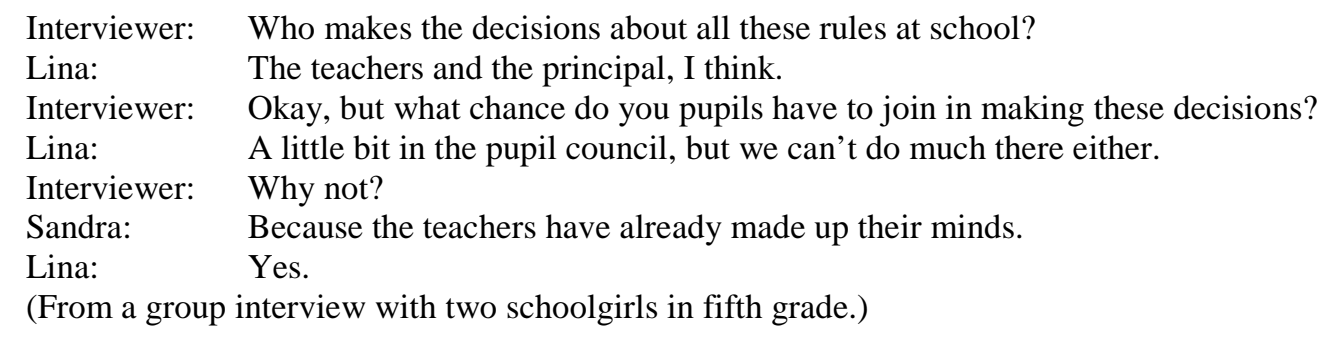

Many pupils are positive about this. They trust in the teachers' competence to make good rules. "They make things fair/.../that all the children have the same rules"' (a girl, kindergarten class). At the same time they mistrust and suppress themselves as rule-makers. "If the pupils decided the rules in school, they would make bad rules. There would be no rules against shouting in classroom, running in corridors, fighting, teasing and so on" (a boy, second grade). As in Sherman's (1996) study, these pupils express an attitude of "the teacher know best'. Furthermore, a lot of pupils say during the interviews that if there were no rules from the adults at the school, the pupils would do a lot of the things currently forbidden, and this would result in chaos and terror. They think that pupils would start to fight, tease, and swear, to run and shout indoors, etc. "It is good that there are rules because otherwise, everyone would be running around during lessons, teasing, fighting, and doing things like that' (a boy, fifth grade). Hence, there is a hidden curriculum of the pupil lacking in moral autonomy, i.e., a construction of pupils who cannot manage without adults and explicit rules, and who cannot participate in real decision-making in school and classroom rules because of childish incompetence.

Interviewer: Do you think you should be able to decide about more things?

Alicia: $\quad$ No, because if you do that you only do things which you think are the most fun, and you won't able to learn so much. Because if we have to learn something, or we really don't know what to do to learn things, like during the maths lesson

wrong. I think it's good that adults decide what you should do in maths.

(From an interview with a girl, fourth grade.)

In the interview material, children are sceptical about their ability to participate in decision-making related to their education. In the excerpt above Alicia gives different reasons for this. One of the reasons is connected with children's image of themselves. Alicia, like other children in the study, expresses the opinion that children are unable to make good decisions because, from her point of view, children just want to do "fun things". Other children with the same opinion say that children 'take the easy way". However, when they actually have decided things in school, the outcome is seldom as negative as the children think. Thus, the image of children as a group of incompetent decision-makers appears to be preconceived rather than experienced. The status of childhood can in many ways be recognized as a condition of "not-yets", where children are measured in terms of lack of experience. Näsman's (2004) research about children and their views on their participation shows that children themselves limit their own claims and expectations concerning what they should be able to decide on. This can be understood as an expression of children's subordination. As in Devine's (2002) study, the findings here show "how children are positioned as subordinate within the school, 
with negative implications for their perception of themselves as active contributors to the schooling process"' (p. 303 ff.). Nevertheless, some of the pupils (especially the older ones) are critical and argue that they should also participate in the decisions about rules. "Well, it's us pupils who go to this school. I kind of think that we should be the ones who decide what rules we should have/- - -/They [the teachers] don't care about what we think or feel, and I think there are a lot of stupid rules, such as not being allowed to wear caps indoors. I mean, wearing a cap in the classroom doesn't make you learn any less', (a girl, fifth grade). Thus, there are two dominant distinct views among the pupils regarding teacher power and their own lack of any say, which in turn can be related to naïve trust as well as negative attitudes because of the lack of grounded trust. Furthermore, even if naïve trust was produced by the teachers' teaching and disciplinary practices across all grades, in accordance with the discourse of development (see Devine, 2000, 2002; Millei \& Raby, 2010), naïve trust was more prevalently nurtured by the teachers in pre-school classes and Grade 2 as compared to teachers in Grades 4 and 5. For example, whereas the teachers in Grade 2 were the ones who talked most in the class councils, the pupils in Grade 4 and 5 talked a lot more in the class councils. This observed link between teachers' practices and children's developmental location might, at least in part, explain why naïve trust was more often expressed among the younger pupils.

\section{The teacher construction of unfair inconsistencies and their trust-reducing effects}

Findings from both research projects show many inconsistencies in teacher behaviour. The complex net of school and classroom rules and teachers' interventions to maintain rules in the everyday life of school are complex and hard for pupils as well as teachers to see in perspective. They contain many inconsistencies, which create some difficulties for pupils when trying to make meaning out of rules and teachers' expectations of appropriate behaviour. Interviews and informal conversations with pupils show that they are critical of these inconsistencies constructed by teachers regarding rules and management. They also express confusion. "Well, but then you don't know what to do"' (a boy, Grade 5). Due to these inconsistencies, the teachers actually create unfairness, according to some pupils.

\footnotetext{
Alice: It's unfair when she [the teacher] asks them the question, although they haven't raised their hands.

Interviewer: What do you mean? Why is it unfair?

Alice: That they still get the question. And the kids who have raised their hands don't get asked [the question], even though we have this rule.

(From a group interview with two girls, fifth grade.)
}

Thus, inconsistencies and perceived injustices in the rules system and in the teachers' intervention behaviour result in criticism and negative attitudes from children. For example, many of them are critical when teachers intervene in a way that is interpreted as unfair (e.g., being stricter with boys than with girls regarding the same rule-transgressions), conducting collective or indiscriminate punishment (e.g., " And those kids who have been quiet, like Maria, get a telling-off too, just because they just happened to be sitting there [around the same table as other classmates who were talking instead of working]', a girl, Grade 5) or when teachers break school rules, such as being indoors during the breaks, using bad language, or chewing gum. The interview data show that pupils interpret these teacher behaviours as odd, wrong or unfair. From the view of the domain theory (Nucci, 2001; Turiel, 2006), this criticism from pupils can be understood as reasoning based on the moral domain of the children's social knowledge, i.e., they morally judge some of the teachers' behaviours as wrong because they associate these behaviours with transgressions of justice.

In many instances, these rule inconsistencies are produced by implicit rules, which are 
unarticulated supplements or exceptions to the explicit rules. This unspoken set of rules can be interpreted as unnoticed background features of everyday life, produced by teachers' corrections of pupils' behaviour (often in forms of disapproving face expressions or commands) in the everyday stream of activities. Because they are not able to see these implicit rules, pupils are not given any opportunity to join teachers in an open discussion or in decision-making processes for developing or revising them. They remain unarticulated and invisible to the pupils, and hence, manifest the power relation between teachers and pupils as well as a negotiation loss for the pupils, since they cannot deliberatively negotiate on rules they are not aware of (for a deeper analysis of inconsistencies in school rules and teachers' rule enforcement, see Thornberg, 2007). Furthermore, although the pupils report that they regard many school rules as good rules, many of them also criticised some rules as bad or wrong if they cannot see the point behind the rule or do not believe the explanation of the rule. In the following excerpt, the boys are talking about teacher's motivation of the "no caps indoors"' rule, by referring to the statements that caps are outdoor clothing and therefore should be taken off in classrooms and other indoor places.

John: A lot of people do actually wear caps indoors-well, not in school because they're not allowed, but they are in other places like McDonalds and places like that.

Alex: The people working there actually wear caps!

(From a group interview with three boys, Grade 5)

A girl in second grade argues, "The thing about caps is that it actually doesn't disturb anyone and you don't start fighting because of them or anything. Why can't you wear them? I really wonder'. Thus, when children perceive rules or teacher explanations of rules as poor or bad, a process of distrust takes shape. These sorts of school rules could be seen as conflicting with what the pupils think should be a matter of personal choice and preferences. As prior research within the domain theory tradition has demonstrated, children are less accepting of adults' constraint when it is used to control their actions in the personal sphere than they are when adult authority is applied to moral or conventional actions (e.g., Nucci, Killen, \& Smetana, 1996; Nucci \& Weber, 1995; Tisak \& Tisak, 1990). In addition, dissonance between teachers' explanations and actions also evokes critical engagement among pupils.

It's strange that we school kids need to get a breath of fresh air to keep up our strength and to concentrate, while they [the teachers] stay indoors during the breaks. Don't they need to get a breath of fresh air too, if it's so really important? They stay indoors almost the whole time during the breaks, but then they get very angry if we stay indoors (a girl, Grade 5).

As in the excerpt above, some pupils actually interpret certain situations as situations where teachers sometimes lie and use deceptive arguments in order to justify certain school rules. Hence, the credibility of teachers as knowledgeable as well as moral authorities is jeopardised from the children's point of view. Furthermore, some pupils also report examples of being treated unfairly and disrespectfully by teachers (and hence, these pupils judge these teacher behaviours to be moral transgressions, cf., Nucci, 2001; Turiel, 2006), which reduces their trust in and respect for their teachers. This in turn can be problematised in terms of teachers as bad role models and rule-breakers.

Gabriel: $\quad$ And we don't get any respect

Interviewer: Is that so?

Gabriel: Yes, and they [the teachers] say that they don't get any, but it's us who don't get any respect.

Interviewer: How does it feel when you don't get any respect? If you feel like that, it's important that you describe what you mean.

David: $\quad$ Look, here‘s an example. For example when we were skating and Adrian didn’t 
want to skate because he didn't want to wear a helmet. Then Karin (teacher) was skating without a helmet and Benham told her that she had to wear a helmet. Then she came and said that we were the rudest children she'd ever met and she said that she would phone our parents and tell them that I didn't go skating. But I didn't have any skates. But if she wasn’t wearing a helmet, Benham shouldn’t be forced to wear one either.

There are also a lot of examples in the data when teachers overrule joint decisions in teaching and instruction, i.e., changing plans made by both the teacher and the pupils about lessons and schoolwork without having any support for these changes in planning from the pupils. All these inconsistencies in teachers' management as well as instruction practices appear to have trust-reducing effects. Without any opportunities for pupil participation in decision-making processes and without good teacher explanations that make sense to the pupils, grounded trust will not be likely to grow among the pupils. The main alternatives are naive trust or negative attitudes as a result of lack of trust.

\section{Discussion}

The result shows that children's influence is limited thus confirming other studies (Aspán, 2009; Devine, 2000, 2002; Dovemark, 2004; Ekholm \& Lindvall, 1991; Fjeldstad \& Mikkelsen, 2003; Forsberg, 2000; Johansson \& Johansson, 2003; Raby, 2008; Raby \& Domitrek, 2007; Selberg, 1999; Thomas \& O’Kane, 1999). Even though teachers have certain ambitions for school democracy and pupil participation, as in the third school in this study, the children's opportunities to have any say are still limited (cf., Aspán, 2009). Inconsistencies, incomprehensibility, and lack of continuity in school appear to hamper pupil participation and ambitions for school democracy. All the schools actually seem to function as what Thomas and O'Kane (1999) called a disempowering system in which children's behaviour and experiences are shaped by controlling forces with few opportunities for them to participate in decision-making or in negotiating rules. In addition, just as Wyness (2009) found that school councils generated hierarchical relations according to age among pupils, which had the effect of muting the voices of the younger children in school, we found that hierarchical relations due to different social status within the peer groups tended to mute the voices of the pupils at the bottom of the social hierarchy during school democracy meetings. According to Denscombe (1985), teachers have to develop certain classroom strategies to establish and maintain classroom control during lessons. One strategy is democratisation, i.e., promoting a high level of participation by pupils in the policies of the school, such as school councils with elected pupil representatives. Nevertheless, "democratisation tends to be illusory and is geared primarily to securing a certain commitment on the part of pupils to the existing social order"' (Denscombe, 1985, 111; also see Millei \& Raby, 2010). A main finding in Denscombe's (1985) study as well as in our research is that even when teachers use progressive strategies (such as democratisation), school and classroom life can still overrule children's voices and participation, being more child-friendly but leaving traditional structures of domination between teachers and pupils intact. The processes of control and obedience have just become slightly subtler (cf., Millei \& Raby, 2010).

Furthermore, our findings shows that many children express a conflict between (a) wanting teachers to decide everything and regarding teachers as more knowledgeable than children, and (b) wanting to have a say in school and becoming distrustful when teachers change things they have decided on together or when teachers decide everything themselves. This might be understood as a result of the tension between (a) the autocratic discourses of discipline and development, in which the pupils are constructed as immature, irrational, and in need of discipline, and (b) democratic discourses of discipline, in which the pupils are con- 
structed as competent agents who have participation rights (see Millei \& Raby, 2010). These conflicting discourses are not only maintained by teachers but also, as a result of schooling, maintained by the pupils. The findings also show that children view many rules in school as good but simultaneously criticise some of them, mistrust some of teachers' rule explanations, experience some rules and teachers' interventions as unfair and inconsistent, and perceive no power over the making of school rules.

Moreover, this study indicates that pupils' perceptions of arbitrary rules, unfair rules and rule applications, rule- and teacher inconsistencies, and bad or poor rule explanations from teachers, appear to lead to criticism and negative attitudes from pupils (a trust-reducing effect), as seen in other studies (e.g., Alerby, 2003; Devine, 2002; Elliott, Witt, Galvin, \& Moe, 1986; Lewis \& Lovegrove, 1987; Scarlett, 1988; Tattum, 1982; Thomson \& Holland, 2002; Williams, 1993). For example, according to a study by Williams (1993), students consider some of their teachers to be insincere and inconsistent, because they do not follow the rules and standards themselves. For instance, these teachers say things like, "you should be kind to others" and "respect others", Yet, students report that they "treat us like babies", they “'don't listen", and they "'have favourites"'. They also report that they talk behind their teachers' backs and "respect"' the teachers only because they "have to". As well as our findings, these support the new sociology of childhood that suggests that children are not just passive recipients but actually active agents in their socialisation process (e.g., Prout \& James, 1997), as well as the domain theory when it argues that children interpret their experiences and reflect upon them. According to the domain theory, some social norms or rules will be accepted while others will be questioned or doubted, or even rejected by them (Neff \& Helwig, 2002; Wainryb, 2006). Hence, children can accept and make sense of some aspects as well as develop critical attitudes to different aspects of social milieus they live in, and oppose or even try to change them (Wainryb, 2006).

Whereas the pupils see school rules that, according to the domain theory (Nucci, 2001; Turiel, 2006), could be identified as moral rules (e.g., no bullying, no teasing, and no fighting) as good and important school rules, many pupils display negative attitudes towards some of the school rules that, according to the domain theory, could be identified as social conventions. When we analysed the pupils' reasoning behind their negative attitudes towards certain conventional school rules from the domain theoretical perspective (Nucci, 2001; Turiel, 2006), we found them to be drawn from the moral domain (conceptions of welfare, justice, and rights) or the personal domain (conceptions of actions that one considers to pertain primarily to oneself and thus to be outside the area of justifiable social regulation) of their social knowledge of right and wrong.

\section{Conclusion}

Our study provides an in-depth examination of young pupils' experiences of democracy, participation and trust in school. Their position is subordinated, their voice is often suppressed, and the value of their voice is minimized. The findings remind us of the gap between political intentions (e.g., Skollagen, 1985:1100, Chapter 1, 2§; Utbildningsdepartementet, 1998) and school practices by voicing schoolchildren's views and experiences of everyday school life regarding democracy, influence, and power. Our empirical results describe a hidden curriculum in everyday school life that counteracts the formal intention of democratic citizenship education. Nevertheless, engaging pupils to have a say and participate in school democratic procedures and practices has to be taken seriously as an educational project. For example, Saha and Print (2010) found that having voted in school elections was positive as it related to feeling prepared to vote as an adult, to being committed to vote at age 18, to political knowledge and participation in peaceful activism. An open classroom climate is a climate 
in which pupils feel free to openly disagree with their teachers about political and social issues in class and in which teachers respect pupils' opinions and encourage pupils to express themselves in class, encourage them to discuss political and social issues about which people have different opinions and present several ideas concerning an issue when explaining it in class (see Fjeldstad \& Mikkelsen, 2003). Pupils' perception of the degree of openness in the classroom climate correlates positively with pupils' civic knowledge and trust in government (Fjeldstad \& Mikkelsen, 2003), and is linked to pupils' political interest, which in turn is related to pupils' democratic values and social engagement (Papanastasiou \& Koutselini, 2003). Our findings reveal a set of obstacles and limitations in everyday school life that have to be addressed in order to create a more open school and classroom climate, and thus involve pupils in democratic practices and prepare them for active participation in democracy beyond school. The findings suggest that as long as such obstacles and limitations implicitly operate as a hidden curriculum in schools, pupil participation is unlikely to be successful even when national laws and political policies of school democracy are in place.

The present study has practical implications. First, the findings indicate that teachers have to enhance their awareness of taken-for-granted power and interaction patterns in everyday school culture, classroom life, and class councils, since these counteract their efforts of making room for school democracy. Second, local politicians and school principals have to support teachers to enable them to work with democracy by operationalizing national political decisions on school democracy into municipal and organisational management of school. As far as we could see, the municipalities responsible for the schools in the current study had not taken any steps to promote deliberative democracy in their schools. Third, even if the teacher training programmes in Sweden educate teacher students about children's rights and school laws and policy documents (in which the aim of school democracy and pupil participation are highlighted), unfortunately there is a widespread lack of instruction and discussion considering deliberative democracy, how to conduct school democracy and how to deal with its obstacles embedded in the school culture and the social psychology of the classroom. Hence, teacher students are not educated in deliberative democracy, and not trained to be aware of and cope with the taken-for-granted norms and power discourses that will hinder them from implementing school democracy. These issues have to be addressed in the curriculum and practice of teacher education. Finally, more research has to be conducted in order to investigate how to erode the obstacles and limitations identified and to positively promote democracy in schools. A possible next stage of research would be to focus on case studies of schools that have achieved a successful democratic life in order to enhance a deeper understanding of how this may be achieved more widely.

\section{References}

Alderson, P. (1999). Human rights and democracy in schools: Do they mean more than picking up litter and not killing whales? The International Journal of Children's Right, 7, 185-205.

Alerby, E. (2003). During the break we have fun: A study concerning pupils' experience of school. Educational Research, 45, 17-28.

Arends, R. I. (1997). Classroom instruction and management. Boston: McGraw-Hill.

Aspán, M. (2009). Delade meningar: Om värdepedagogiska invitationer för barns inflytande och inkännande. [Shared and devided minds: On affordances in education for participant and sympathetic children]. Stockholm: Stockholm University.

Bernstein, B. (2000). Pedagogy, symbolic control and identity: Theory, research, critique (rev. ed.). Lanham: Rowman \& Littlefield Publishers.

Charmaz, K. (2006). Constructing grounded theory: A practical guide through qualitative analysis. London: Sage.

Corsaro, W. A. (2005). The sociology of childhood (2nd ed.). Thousand Oaks: Pine Forge Press.

Corsaro, W. A., \& Molinari, L. (2000). Entering and observing in children's worlds: A reflection on a longitudinal ethnography of early education in Italy. In P. Christensen \& A. James (Eds.), Re- 
search with children (pp. 179-200). London: Falmer Press.

Davies, L. (2000). Researching democratic understanding in primary school. Research in Education, 61, 39-48.

Denscombe, M. (1985). Classroom control: A sociological perspective. London: George Allen \& Unwin.

Devine, D. (2000). Constructions of childhood in school: Power, policy and practice in Irish education. International Studies in Sociology of Education, 10, 23-41.

Devine, D. (2002). Children's citizenship and the structuring of adult-child relations in the primary school. Childhood, 9, 303-320.

Dewey, J. (1916). Democracy in education. New York: Macmillan.

Dovemark, M. (2004). Ansvar-flexibilitet-valfrihet: En etnografisk studie om en skola i förändring. [Responsibility-flexibility-choice: An ethnographic study on a school in change]. Göteborg Studies in Educational Sciences, 223. Göteborg: Göteborg University.

Ekholm, M., \& Lindvall, K. (1991). Eleverna och demokratin i skolan: Enkätbelysning och en värderande diskussion. [Pupils and democracy in school: A questionnaire study and an evaluating discussion]. Karlstad: Karlstad University.

Elliott, S. N., Witt, J. C., Galvin, G. A., \& Moe, G. L. (1986). Children’s involvement in intervention selection: Acceptability of interventions for misbehaving peers. Professional Psychology: Research and Practice, 17, 235-241.

Englund, T. (2000). Deliberativa samtal som värdegrund - historiska perspektiv och aktuella förutsättningar. [Deliberative communication as a value foundation - historical perspective and current preconditions]. Stockholm: Skolverket.

Englund, T. (2006). Deliberative communication: A pragmatist proposal. Journal of Curriculum Studies, 38, 503-520.

Fjeldstad, D., \& Mikkelsen, R. (2003). Strong democratic competence does not automatically lead to strong engagement and participation. International Journal of Educational Research, 39, 621632.

Forsberg, E. (2000). Elevinflytandets många ansikten. [The many faces of pupil participation]. Uppsala Studies in Education, 93. Uppsala: Uppsala University.

Fox, R. M., \& DeMarco, J. P. (2001). Moral reasoning (2nd ed.). Fort Worth, TX: Harcourt College Publishers.

Glaser, B. G., \& Strauss, A. L. (1967). The discovery of grounded theory. New York: Aldine de Gruyter.

Gutmann, A. (1987). Democratic education. Princeton, JN: Princeton University Press.

Helwig, C. C. (2006). The development of personal autonomy throughout cultures. Cognitive Development, 21, 468-473.

Jackson, P. W. (1968). Life in classroom. New York: Teachers College Press.

James, A., Jenks, C., \& Prout, A. (2001). Theorizing childhood. Cambridge: Polity Press.

Johansson, E., \& Johansson, B. (2003). Etiska möten i skolan. [Ethical encounters in the school]. Stockholm: Liber.

Lewis, R., \& Lovegrove, M. N. (1987). What students think of teacher's classroom control techniques: Results from four studies. In J. Hastings \& J. Schwieso (Eds.), New directions in educational psychology. Vol. 2. Behaviour and motivation (pp. 93-113). London: Falmer Press.

Neff, K. D., \& Helwig, C. C. (2002). A constructivist approach to understanding the development of reasoning about rights and authority within cultural contexts. Cognitive Development, 17, 14291450.

Mandell, N. (1991). The least-adult role in studying children. In F. C. Waksler (Ed.), Studying the social worlds of children: Sociological readings (pp. 38-59). London: Falmer Press.

Mayall, B. (2000). Conversations with children: Working with generational issues. In P. Christensen \& A. James (Eds.), Research with children (pp. 120-135). London: Falmer Press.

Meighan, R., \& Siraj-Blatchford, I. (1997). A sociology of education (3rd ed.). London: Cassell.

Milgram, S. (1974). Obedience to authority. Cambridge: Cambridge University Press.

Millei, Z., \& Raby, R. (2010). Embodied logic: Understanding discipline through constituting the subject of discipline. In Z. Millei, T. G. Griffiths, \& R. J. Parkes (Eds.), Re-theorizing discipline in education (pp. 27-42). New York, NY: Peter Lang. 
Näsman, E. (2004). Barn, barndom och barns ra ttigheter [Children, childhood and children's rights]. In L. Olsen (Ed.), Barns makt [Children’s power] (pp. 53-75). Uppsala: Justus.

Nucci, L. P. (2001). Education in the moral domain. Cambridge: Cambridge University Press.

Nucci, L. P., Killen, M., \& Smetana, G. (1996). Autonomy and the personal: negotiation and social reciprocity in adult-child social exchanges. In (Series Ed.) \& \& M. Killen (Vol. Eds.), New Directions for Child Development: Vol. 73. Children's autonomy, social competence, and interactions with adults and other children: exploring connections and consequences (pp. 7-24). San Francisco: Jossey-Bass Publishers.

Nucci, L., \& Weber, E. K. (1995). Social interactions in the home and the development of young children's conceptions of the personal. Child Development, 66, 1438-1452.

Papanastasiou, C., \& Koutselini, M. (2003). Developmental model of democratic values and attitudes toward social actions. International Journal of Educational Research, 39, 539-549.

Portelli, J. P. (1993). Exposing the hidden curriculum. Journal of Curriculum Studies, 25, 343-358.

Prout, A. (2002). Researching children as social actors: An introduction to the Children 5-16 Programme. Children \& Society, 16, 67-76.

Prout, A., \& James, A. (1997). A new paradigm for the sociology of childhood? Provenance, promise and problems. In A. James \& A. Prout (Eds.), Constructing and reconstructing childhood (2nd ed., pp. 7-33). London: The Falmer Press.

Raby, R. (2005). Polite, well-dressed and on time: Secondary school conduct codes and the production of docile citizens. Canadian Review of Sociology and Anthropology, 42, 71-92.

Raby, R. (2008). Frustrated, resigned, outspoken: Students' engagement with school rules and some implications for participatory citizenship. The International Journal of Children's Right, 16, 7798.

Raby, R., \& Domitrek, J. (2007). Slippery as fish... but already caught? Secondary students' engagement with school rules. Canadian Journal of Education, 30, 931-958.

Saha, L. J., \& Print, M. (2010). Student school elections and political engagement: A cradle of democracy? International Journal of Educational Research, 49, 22-32.

Scarlett, P. (1988). Discipline: Pupil and teacher perceptions. Maladjustment and Therapeutic Education, 7, 169-177.

Selberg, G. (1999). Elevinflytande i lärande. [Pupil participation in learning]. Luleå: Luleå University of Technology.

Sherman, A. (1996). Rules, routines and regimentation. Nottingham: Educational Heretics Press.

Skelton, A. (1997). Studying hidden curricula: Developing a perspective in the light of postmodern insights. Curriculum Studies, 5, 177-193.

Skollagen [Education Act] (1985:1100). Retrieved May 20, 2008 from the Swedish Parliament web page: http://www.riksdagen.se/Webbnav/index.aspx? nid=3911\&bet=1985:1100.

Skolverket [National Agency for Education]. (2000). En fördjupad studie om värdegrunden - om möten, relationer och samtal som förutsättningar för arbetet med de grundläggande värdena. [An in-depth study of the value foundation-encounters, relationships and conversations as necessary conditions for the development of basic values] (Dnr 2000:1613). Stockholm: Skolverket.

Skolverket [National Agency for Education]. (2006). Ordningsregler för en trygg och lärande miljö. [Rules of order conducive to a safe and learning school milieu]. Stockholm: Skolverket.

Smetana, J. G. (2006). Social-cognitive domain theory: Consistencies and variations in children's moral and social judgments. In M. Killen \& J. G. Smetana (Eds.), Handbook of moral development (pp. 119-153). Mahwah, NJ: Lawrence Erlbaum.

Tattum, D. (1982). Disruptive pupils in schools and units. Chichester: John Wiley \& Sons. N., \& O'Kane, C. (1999). Experiences of decision-making in middle childhood: The example of children looked after by local authorities. Childhood, 6, 369-387.

Thomson, R., \& Holland, J. (2002). Young people, social change and the negotiation of moral authority. Children \& Society, 16, 103-115.

Thornberg, R. (2007). Inconsistencies in everyday patterns of school rules. Ethnography and Education, 2, 401-416.

Thornberg, R. (2010). School democratic meetings: Pupil control discourse in disguise. Teaching and Teacher Education, 26, 924-932.

Thorne, B. (1993). Genderplay. Buckingham: Open University Press. 
Tisak, M. S., \& Tisak, J. (1990). Children’s conceptions of parental authority, friendship, and sibling relations. Merrill-Palmer Quarterly, 36, 347-367.

Turiel, E. (1983). The development of social knowledge: Morality and convention. Cambridge: Cambridge University Press.

Turiel, E. (2006). The development of morality. In W. Damon (Series Ed.) \& N. Eisenberg (Vol. Ed.), Handbook of child development. Vol. 3. Social, emotional, and personality development (6th ed., pp. 789-857). New York: Wiley.

Utbildningsdepartementet [the Ministry of Education and Research]. (1998). Läroplan för det obligatoriska skolväendet, förskoleklassen och fritidshemmet, Lpo 94. [The National curriculum policy document for the primary school system, preschool classes and after-school centres]. Stockholm: Skolverket.

United Nations of the Convention on the Rights of the Child (1989). Retrieved May 20, 2008 from the Office of the High Commissioner for Human Rights: http:// www.unhchr.ch/html/menu3/b/k2crc.htm.

Vallance, E. (1983). Hiding the hidden curriculum. In H. Giroux \& D. Purpel (Eds.), The hidden curriculum and moral education (pp. 9-27). Berkeley: McCutchan Publishing Corporation.

Wainryb, C. (2006). Moral development in culture: Diversity, tolerance, and justice. In M. Killen \& J. G. Smetana (Eds.), Handbook of moral development (pp. 211-240). New Jersey: Lawrence Erlbaum Associates.

Williams, M. M. (1993). Actions speak louder than words: What students think. Educational Leadership, 51(3), 22-23.

Wyness, M. (2009). Children representing children: Participation and the problem of diversity in UK youth councils. Childhood, 16, 535-552. 